\title{
Empirical Researches on International Economic Based on Complete Trade Model
}

\author{
Qunli Wu ${ }^{1, a}$, Ye Yuan ${ }^{2, b,{ }^{*}}$ \\ ${ }^{1,2}$ School of Economics and Management, North China Electric Power University, \\ Baoding 071003, Hebei Province, China \\ bemail:yuan2015work@126.com
}

Keywords: Indirect trade, Complete trade model, International economic.

Abstract. With the continuous development of economic globalization and trade links between the world ever closer, more international trade includes direct and indirect trade links, so there is an urgent need for a method to analyze the problems associated with the international economy. This paper creates a complete trade model, through the trade data by 99 countries in 2013 into this model to analysis the correlation of international economy. The results showed that, compared to the direct trade, using complete trade model could analysis the international economic ties more complete, more accurate.

\section{Introduction}

Along with the popularity and development of economic globalization, it is pounding us the daily life of each person. All countries should actively implement policies of opening-up and try to exert its advantages to conform to situation, adapting itself to the development of the world and following the step of the time. And international trade plays an important role between those countries, foreign trade means not only being associated with the world, but also promoting economic development, the appropriate trade policies can stimulate economic growth and promote employment, which also balance supply and demand. For our part, with the rapid growth of turnover of foreign trade, imports and exports growth rate had at one point exceeded 35\% , even more than GDP.

With the development of global economic integration and international trade expanded rapidly, the volume of trade between countries has been far more than statistical bilateral data, as trade between countries may include direct and indirect trade. It's imperfect to suppose that only analyzing the direct trade which may make us with an incomplete view to pay attention to the world economy so as to obtain the conclusion. For example, the laptop components exported by Japan to China will be assembled and manufactured, and then the end product will be exported to the United state. In this process, Japan and the United States have indirect trade through intermediaries, so we can not directly calculate the amount of China's exports to the United States. As can be seen, to reflect the real situation of foreign trade under the current economic situation, indirect trade and direct trade should be considered when analyzing trade between countries. So there is important significance for the research on indirect trade in international trade.

\section{The establish of complete trade model}

Input-output model has three balance relationship, line balance, column balance, the total balance. Only to achieve the above three conditions, it is considered to establish the correct input-output table, use the formula to express is:

$$
\begin{gathered}
\text { Intermediate use }+ \text { final use }=\text { total output } \\
\text { Intermediate inputs }+ \text { initial investment }=\text { Total investment } \\
\text { Total input }=\text { total output }
\end{gathered}
$$


Similarly, we establish the complete trade model by the following table 1, in order to reflect the mutual trade as the core of balance. The variables are defined as follows: Xij refers to bilateral export from country $i$ to country $\mathrm{j}$, and according to the definition in macroeconomics, gross domestic product $(\mathrm{GDP})=$ consumption $(\mathrm{C})+$ investment $(\mathrm{I})+$ government purchase $(\mathrm{G})+$ net exports $(\mathrm{E}-\mathrm{M})$, you can get similar formula of balance equation as (1) and (2):

A country's overall demand $\mathrm{Y}=$ export demand $\mathrm{E}+$ domestic demand $\mathrm{Y}^{\mathrm{D}}$ (consumption + investment + government purchase $)=\mathrm{E}+\mathrm{C}+\mathrm{I}+\mathrm{G}$

$$
\text { A country's aggregate supply } \mathrm{Y}=\mathrm{GDP}+\text { imports } \mathrm{M}
$$

Combined with the formula (4) (5) can be concluded that the aggregate balance equation:

$$
\begin{aligned}
& \text { A country's overall demand }(\mathrm{E}+\mathrm{C}+\mathrm{I}+\mathrm{G})=\text { a country's aggregate supply } \\
& \qquad \mathrm{GDP}=\mathrm{C}+\mathrm{I}+\mathrm{G}+(\mathrm{E}-\mathrm{M})
\end{aligned}
$$

Finally concluded (7) consistent with the concept of macroeconomics of GDP,so the complete international trade model based on input-output mode accordance with the basic balance, and can

\begin{tabular}{|c|c|c|c|c|c|}
\hline \multirow{2}{*}{\multicolumn{2}{|c|}{ Aggregate }} & \multicolumn{2}{|c|}{ Imports of country $\mathrm{j}$} & \multirow{2}{*}{$\begin{array}{l}\text { Domestic demand } \\
\text { Consumption(C) investment } \\
\text { (I) government purchase(G) }\end{array}$} & \multirow{2}{*}{$\begin{array}{l}\text { Aggregate } \\
\text { demand }\end{array}$} \\
\hline & & $12 \ldots n$ & subtotal & & \\
\hline \multirow{4}{*}{$\begin{array}{c}\text { emports of } \\
\text { country i }\end{array}$} & 1 & $\mathrm{X}_{11} \mathrm{X}_{12} \ldots \mathrm{X}_{1 \mathrm{n}}$ & $\mathrm{E}_{1}$ & \multirow{4}{*}{$\begin{array}{c}\mathrm{Y}^{\mathrm{D}}=\text { consumption }(\mathrm{C})+ \\
\text { investment }(\mathrm{I})+\text { government } \\
\text { purchase }(\mathrm{G})\end{array}$} & $\mathrm{Y}_{1}$ \\
\hline & 2 & $X_{21} X_{22} \ldots X_{2 n}$ & $\mathrm{E}_{2}$ & & $\mathrm{Y}_{2}$ \\
\hline & $\vdots$ & $\ldots \mathrm{X}_{\mathrm{ij}} \ldots$ & $\vdots$ & & $\vdots$ \\
\hline & $\mathrm{n}$ & $\mathrm{X}_{\mathrm{n} 1} \mathrm{X}_{\mathrm{n} 2} \ldots \mathrm{X}_{\mathrm{nn}}$ & $E_{n}$ & & $Y_{n}$ \\
\hline subtotal & & $M_{1} M_{2} \ldots M_{n}$ & & & \\
\hline $\begin{array}{l}\text { new value } \\
\text { of } \\
\text { domestic }\end{array}$ & $\begin{array}{c}\mathrm{GDP}=\mathrm{C}+\mathrm{I}+ \\
\mathrm{G}+(\mathrm{E}-\mathrm{M})\end{array}$ & $\mathrm{GDP}_{1} \ldots \mathrm{GDP}_{\mathrm{n}}$ & & & \\
\hline \multicolumn{2}{|c|}{ Aggregate supply } & $\mathrm{Y}_{1} \mathrm{Y}_{2} \ldots \mathrm{Y}_{\mathrm{n}}$ & & & \\
\hline
\end{tabular}
reflect the state of mutual trade relations, and the variables are shown in table 1 below.

Table 1. The complete international trade model

Definition of direct trade coefficients $\mathrm{a}_{\mathrm{ij}}$ is per unit of aggregate supply of country $\mathrm{j}$ need direct consumption imports from country i in international trade. Definition of complete trade coefficients $b_{i j}$ is per unit of aggregate supply of country $j$ need the sum of direct and indirect valueof imports from country i.

The direct trade coefficient is calculated as follows:

$$
\mathrm{a}_{\mathrm{ij}}=\mathrm{x}_{\mathrm{ij}} / \mathrm{Y}_{\mathrm{i}}(\mathrm{i}, \mathrm{j}=1,2, \ldots, \mathrm{n})
$$

In equation (8) $Y_{j}=M n+$ GDPn $(n=1,2,3 \ldots)$, meaning devides the total export from countries $i$ to country $\mathrm{j}$ by the sun of total imports and GDP of country $\mathrm{j}$. We then let complete trade coefficient $\mathrm{b}_{\mathrm{ij}}$ referred to sum of direct trade coefficient and all indirect trade coefficients.

With the formula is expressed as:

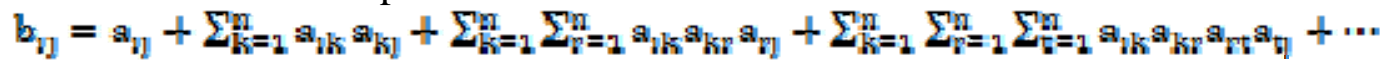


On the right side of equation (9) respectively direct trade coefficient, first round of indirect trade coefficient, second round indirect trade coefficient, etc., and contains all the indirect trade coefficients. In practice, if using formula(9) to calculate will be very cumbersome and complex, so can only use direct trsde coefficient to calculate complete trade coefficient.

Make matrix A be direct trade coefficient matrix, $\mathrm{X}^{(0)}$ stands for when all countries increase per unit of product aggregate demand driven by countries direct exports matrix, so $\mathrm{X}^{(0)}=\mathrm{AI}=\mathrm{A}$, ( $\mathrm{I}$ as the identity matrix).

The first round of indirect trade forms the matrix is:

$$
\mathrm{X}^{(1)}=\mathrm{AX}^{(0)}=\mathrm{A}^{2} \mathrm{I}=\mathrm{A}^{2}
$$

The second round of indirect trade forms the matrix is:

$$
\mathrm{X}^{(2)}=\mathrm{AX} \mathrm{X}^{(1)}=\mathrm{A}^{3} \mathrm{I}=\mathrm{A}^{3}
$$

Then the kth round of indirect trade forms the matrix is:

$$
\mathrm{X}^{(\mathrm{k})}=\mathrm{AX} \mathrm{X}^{(\mathrm{k}-1)}=\mathrm{A}^{\mathrm{k}+1} \mathrm{I}=\mathrm{A}^{\mathrm{k}+1}
$$

So when all countries increase per unit aggregate demand, the complete trade coefficient matrix B it forms can be represented as:

$$
\mathrm{B}=\mathrm{A}+\mathrm{A}^{2}+\mathrm{A}^{3}+\ldots+\mathrm{A}^{\mathrm{K}+1}+\mathrm{A}^{\mathrm{K}}+\ldots
$$

As $\sum_{i=1}^{n} a_{i j}<\mathbb{1}$, so matrix is convergent,we can derive:

$$
\begin{array}{r}
(I-A)^{-1}=I+A+A^{2}+A^{3}+\ldots \\
\text { so, } A+A^{2}+A^{3}+\ldots=(I-A)^{-1}-I
\end{array}
$$

The complete trade coefficient matrix is

$$
B=(I-A)^{-1}-I \text {. }
$$

\section{The comparison between direct trade coefficient and complete trade coefficient}

This section first calculates the complete trade data matrix B and the direct trade coefficient matrix A with the trade data of 99 countries. Due to limited space, in order to verify the advantages of this model, intercepts some of the complete and direct trade series of countries with China, after sorting take the first 10 countries, contrast the differences between them. Because the data in the table is the per unit aggregate supply need direct consumption proportion of imports in the process of trade. To reflect the division of the results, multiplied the result by 1000, on behalf of the aggregate demand for each additional $\$ 1000$ in china when boosts completely trade and direct trade in other countries. The comparison between the two results is as follows:

Table 2.Each additional \$1000 of aggregate demand in china boosts trade volume(US dollar)

\begin{tabular}{ccc}
\hline country & direct trade volume & complete trade volume \\
\hline Hongkong, China & 30.1943 & 31.2499 \\
\hline Korea & 13.73431 & 15.82884 \\
\hline U.S.A & 11.48841 & 15.73235 \\
\hline Japan & 12.18376 & 15.31052 \\
\hline Germany & 8.42328 & 10.69267 \\
\hline Australia & 8.22079 & 8.921485 \\
\hline Singapore & 4.55426 & 7.212462 \\
\hline Brazil & 4.33358 & 4.824922 \\
\hline Russia & 3.35430 & 4.094844 \\
\hline Malaysia & 2.89860 & 4.083843
\end{tabular}

Through the above table can be intuitive to see that when considering indirect trade, the total trade volume compared with the direct trade is greater. As far as Malaysia is concerned, its trade volume has increased by more than $40 \%$ after considering indirect trade, consistent with the model's 
expectations, the main reason of this result is that the direct trade coefficient matrix only takes into account the bilateral import and export relations, but does not include indirect trade into the scope of calculation.

But in actual countries foreign trade, some countries have a lower direct international trade volume while may have a higher indirect trade volume. Compared with the single use of the direct trade coefficient, the full trade coefficient has a greater advantage in the study of national economic relevance, which can be more comprehensive, complete and accurate in studying international economic relations.

\section{Summary}

This article created a complete business model, by using trade data of 99 countries in 2013 analysis the international economic linkage. The results obtained can better reflect the world status and role in the international economic system, and compared to the direct trade, the complete teade model can be drawn entirely clearer trade indicators, more complete, more accurate measure of international economic ties .

Meanwhile, the complete trade model can not only analysis completely effective associated in trading system and the international economy, and also could forecast the world economy, which can provide reference for the study of the current global trade integration.

Overall, this article can only obtain economic linkages between the world economy, for some specific issues, such as trade structure, trade friction and so on through this result can not be better presented.So should be considered with other methods combined, which is also need attention in future studies.

\section{References}

[1] K. Cheewatrakoolpong, S. Manprasert, Trade linkages and crisis spillovers, Asian Economic Papers, vol.13, pp, 84-103, 2014.

[2] K . Cheewatrakoolpong and S. Manprasert, Trade concentration and crisis spillover: Case study of transmission of the subprime crisis to Thailand. ARTNeT Working Paper Series No. 112. Bangkok: UNESCAP, 2012.

[3] Liu Hongtao, Xi Youmin and Guo Jue, Energy embodied in the international trade of China: An energy input-output analysis, Energy Policy, vol.8, 2010.

[4] Anderson James E.A Theoretical Foundation for the Gravity Equation[J].American Economic Review, 69:106- 16, 1979.

[5] Bergstrand Jeffrey H. The generalized gravity equation, monopolistic competition and the factorproportions theory in international trade, The Review of Economics and Statistics, 71 (1): 143153, 1989. 